\title{
進行期股関節症に対する寬骨臼回転骨切り術の成績
}

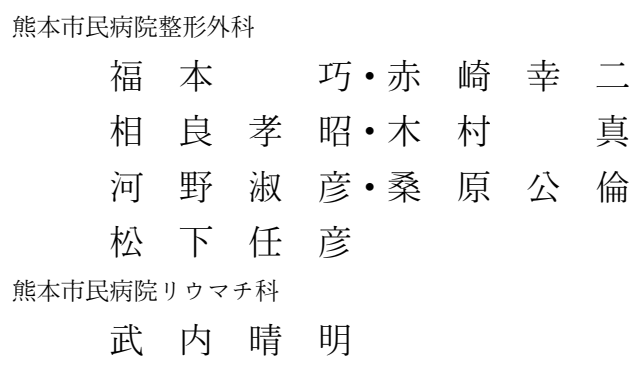

\section{Results of Ratational Acetabular Osteotomy for Advanced Osteoarthritis of the Hip}

\author{
Takumi Fukumoto, Koji Akasaki, Takaaki Sagara, \\ Makoto Kimura, Toshihiko Kouno, Korin Kuwahara, \\ and Hidehiko Matsushita \\ Department of Orthopaedic Surgery, Kumamoto City Hospital, \\ Kumamoto, Japan \\ Haruaki Takeuchi \\ Department of Rheumatology, Kumamoto City Hospital, \\ Kumamoto, Japan
}

\begin{abstract}
We studied the results of 25 rotational acetabular osteotomies (RAO) for advanced osteoarthritis of the hip. All patients were female. The average age at operation was 43 years (range : 30 to 55 years). The average duration of follow-up was 3.2 years (range : 1 to 7.3 years).

The CE angle, AC angle, and AHI significantly improved in all patients after surgery. At the time of follow-up, the average Japanese Orthopaedic Association hip score improved from 64 to 89 . Five joints showed progression of degenerative changes. These patients indicated advanced osteoarthritis also in the opposite hip. No patient had secondary total hip arthroplasty (THA).

We conclude that RAO can improve the advanced osteoarthritis of the hip and delay the indication for THA.
\end{abstract}

Key words : rotational acetabular osteotomy（寛骨臼回転骨切り術），osteoarthritis of the hip (変形 性股関節症), advanced stage（進行期）

\section{はじめに}

寛骨臼回転骨切り術（以下 RAO）の，前及び初期 股関節症に対する成績は良好であるが，進行期股関節 症に対する成績はかならずしも安定していない，今回，
$\mathrm{RAO}$ を施行した進行期股関節症について調查し，そ の術後成績に影響する因子について検討した。

\section{対象と方 法}

対象は進行期股関節症に対してRAOを施行し, 術 
後 1 年以上観察できた 22 例 25 関節で，全例女性，手 術時平均年令 $43 （ 30 \sim 55 ）$ 才, 平均観察期間は 3 年 2 ヶ月（1〜 7 年 3 ヶ月）であった。合併手術は, 大 腿骨外反骨切り術 2 関節, 大腿骨内反骨切り術 1 関節

\begin{tabular}{|c|c|c|c|}
\hline & 術前 & 術後 & 観察時 \\
\hline JOA score & 64 & & 89 \\
\hline $\mathrm{CE}$ 角 $\left(^{\circ}\right)$ & 5.4 & $37.6^{*}$ & 40.4 \\
\hline $\mathrm{AC}$ 角 $\left(^{\circ}\right)$ & 25.0 & $1.0^{*}$ & 2.7 \\
\hline AHI (\%) & 55.3 & $85.8^{*}$ & 87.1 \\
\hline 関節裂隙 $(\mathrm{mm})$ & 1.2 & 2.7 & 2.6 \\
\hline 骨頭外方指数 & 1.65 & 1.68 & 1.69 \\
\hline 骨頭上方指数 & 0.37 & 0.44 & 0.46 \\
\hline
\end{tabular}

${ }^{*} \mathrm{P}<0.01$ vs 術前

表 2 裂隙改善例, 狭小例での比較

\begin{tabular}{l|cc}
\hline \hline & 裂隙改善例 & 裂隙狭小例 \\
\hline 関節数 (\%) & $20(80)$ & $5(20)$ \\
年令 (才) & 42.7 & 43.4 \\
$\mathrm{CE}$ 角 $\left(^{\circ}\right)$ & 36.9 & 40.6 \\
$\mathrm{AC}$ 角 $\left(^{\circ}\right)$ & 0.9 & 1.2 \\
$\mathrm{AHI}(\%)$ & 85.0 & 88.8 \\
関節裂隙 $(\mathrm{mm})$ & 2.6 & 3.4 \\
骨頭外方指数 & 1.69 & 1.66 \\
骨頭上方指数 & 0.45 & 0.39 \\
対側股関節症 (\%) & $5 / 20(25)$ & $5 / 5(100)^{*}$ \\
\hline \multicolumn{2}{|c}{${ }^{*} \mathrm{P}<0.01$}
\end{tabular}

であった，方法は，臨床的には術前及び最終観察時の JOA score について調査し，X線学的には術前，術 直後及び最終観察時での $\mathrm{CE}$ 角, $\mathrm{AC}$ 角, $\mathrm{AHI}$ ，関節 裂隙, 骨頭外方指数, 骨頭上方指数について計測した.

結

\section{果}

JOA score は術前平均 64 点から観察時平均 89 点 に改善した. CE 角は術前平均 $5.4^{\circ}$ から術後平均 $37.6^{\circ}$ に, $\mathrm{AC}$ 角は術前平均 $25^{\circ}$ から術後平均 $1^{\circ}$ に, $\mathrm{AHI}$ は術前平均 $55.3 \%$ から術後平均 $85.8 \%$ に有意に改善 した $(\mathrm{p}<0.01)$. 関節裂隙は術前平均 $1.2 \mathrm{~mm}$ から術 後平均 $2.7 \mathrm{~mm}$ に開大した。骨頭外方指数は術前平均 1.65 から術後平均 1.68 に, 骨頭上方指数は術前平均 0.37 から術後平均 0.44 となり, 平均 $5 \mathrm{~mm}$ の上方化 が見られた（表 1 ）.

術直後から観察時にかけて関節裂隙が不变もしくは 改善した例と狭小化した例に分けて，成績に影響する 因子について比較した。この 2 群間では, 年令, 術直 後の CE 角, AC 角, AHI，関節裂隙，骨頭外方指数， 骨頭上方指数に有意差はなかったが，対側が股関節症 である場合のみ有意差を認めた（ $\mathrm{p}<0.01 ） （$ 表 $2 ）$.

骨癒合不全，臼蓋壊死，感染等の合併症はなく，観 察時 THA となった症例むなかった。

症例

症例 $1 ： 49$ 才女性，左進行期股関節症

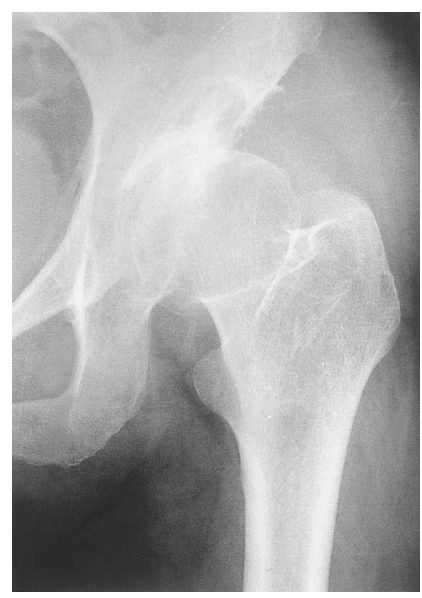

術前

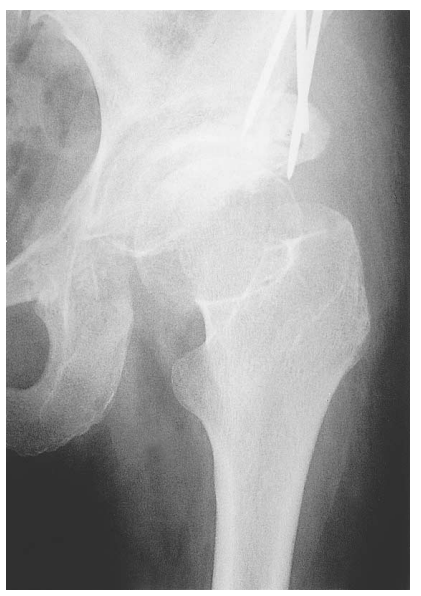

術直後

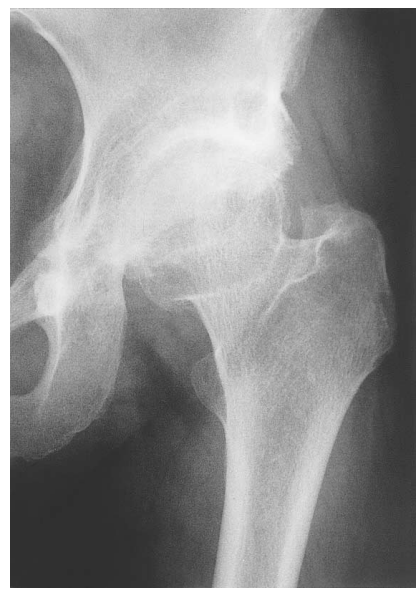

術後 4 年 3 ヶ月

図149才女性, 左進行期股関節症 


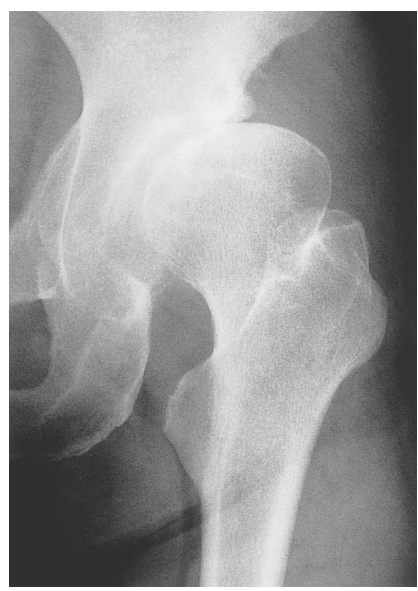

術前

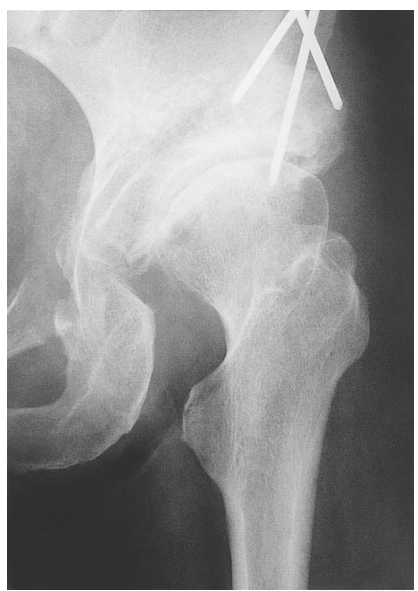

術直後

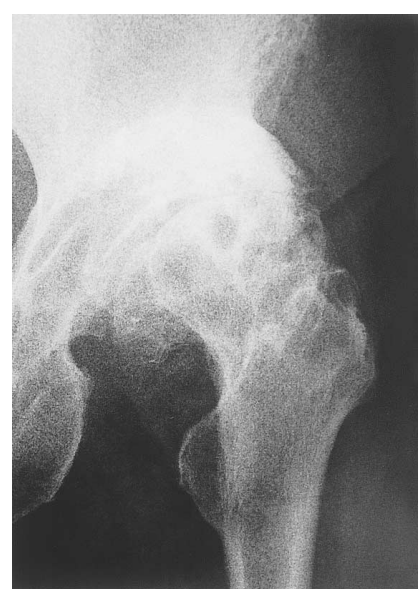

術後 4 年 9 ヶ月

図 236 才女性, 左進行期股関節症

CE 角は術前 $4^{\circ}$ から術後 $35^{\circ}$ に, AC 角は術前 $24^{\circ}$ から術後 $3^{\circ}$ に改善した。 JOA score は術前 53 点か ら術後 4 年 3 ヶ月の時点で 92 点に改善し, 関節裂隙 あ保たれている(図1).

症例 $2 ： 36$ 才女性, 両側進行期股関節症

$\mathrm{CE}$ 角は術前 $-11^{\circ}$ から術後 $43^{\circ}$ に, $\mathrm{AC}$ 角は術前 $25^{\circ}$ から術後 $3^{\circ}$ に改善したが，その後関節列隙が狭小化 した. JOA score は術前 59 点から術後 5 年時点で 68 点で, 対側は末期股関節症となり THA を施行した (㘡 2 ).

\section{考察}

進行期股関節症に対する RAOの適応として，田

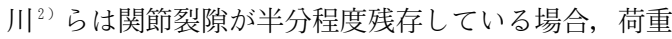
部関節裂隙が消失している場合には回転移動後に新し く荷重部となるべき部位の関節裂隙が半分程度以上残 存している場合，ただし年令は 45 才以下が望ましい とした。今回の症例でも術直後は全例関節裂隙は開大 し，80\%の症例では関節裂隙が維持されていた。裂隙 が狭小化した 5 例では, 年令, X 線パラメーター上 は有意差はなかったが，全例対側が進行期以上の股関 節症であった。そのうち 2 例は後にTHA となり，他 の 2 例は RAO を施行した. 西野 ${ }^{1)}$, 上田 ${ }^{3)}$ らも進行 期に対する RAO では，反対側の支持性が関節症の進 行防止に重要であるとしている．股関節症の状態に応 じて対側の THA あるいは骨切り術を考慮すべきであ
り，またその順序，タイミングあ重要であると考えら れる。

また，関節裂隙が狭小化した 5 例のうち 2 例は末期 に進行し，両側例であることに加えて，1例は荷重部 水平化が不十分 $\left(11^{\circ}\right)$ であったこと，他の例（症例 2 ）は骨頭が外方化したこと（骨頭外方指数1.89）が 原因として考えられた。他の 3 例では裂隙は狭小化し たものの列隙幅は均一にリモデリングされており，荷 重部の水平化，骨頭の十分な被覆による力学的に安定 した関節を作ることにより, 関節症の進行を遅らせ, THA に対する time saving 効果ああると考えられる.

\section{ま と め}

進行期股関節症 22 例 25 関節に対して RAO を施行 し，80\%の症例で関節症の進行を防止できた。

術後の成績には対側の支持性が重要であり，状態に 応じて骨切り術, THA を考慮する必要がある.

関節症進行例でも THA に対する time saving 効果 があると考えられる。

\section{参 考 文 献}

1）西野 暢ら：進行期变股症における寛骨臼回転骨切り 術の中期成績. 中部整災誌，40：839-840，1997.

2）田川 宏：寛骨臼回転骨切り術. 臨床整形外科, 24： 173-181, 1989.

3）上田 剛ら：進行期股関節症に対する寛骨臼回転骨切 り術の成績。中部整災誌，40：837-838，1997. 